Article

\title{
Assessment of Yield and Nitrate Content of Wall Rocket Grown under Diffuse-Light- or Clear-Plastic Films and Subjected to Different Nitrogen Fertilization Levels and Biostimulant Application
}

\author{
Ida Di Mola ${ }^{1}(\mathbb{D})$, Lucia Ottaiano ${ }^{1, *(\mathbb{D})}$, Eugenio Cozzolino ${ }^{2}(\mathbb{D})$, Christophe El-Nakhel ${ }^{1}(\mathbb{D})$, Massimo Rippa ${ }^{3}(\mathbb{D})$ \\ Pasquale Mormile ${ }^{3}$, Giandomenico Corrado ${ }^{1}$ (D), Youssef Rouphael ${ }^{1}$ (D) and Mauro Mori ${ }^{1}$
}

1 Department of Agricultural Sciences, University of Naples Federico II, 80055 Portici, Italy; ida.dimola@unina.it (I.D.M.); christophe.elnakhel@unina.it (C.E.-N.); giandomenico.corrado@unina.it (G.C.); youssef.rouphael@unina.it (Y.R.); mori@unina.it (M.M.)

2 Council for Agricultural Research and Economics (CREA)-Research Center for Cereal and Industrial Crops, 81100 Caserta, Italy; eugenio.cozzolino@crea.gov.it

3 Institute of Applied Science and Intelligent Systems of National Research Council (ISASI-CNR), 80078 Pozzuoli, Italy; m.rippa@isasi.cnr.it (M.R.); p.mormile@isasi.cnr.it (P.M.)

* Correspondence: lucia.ottaiano@unina.it

check for

updates

Citation: Di Mola, I.; Ottaiano, L.; Cozzolino, E.; El-Nakhel, C.; Rippa, M.; Mormile, P.; Corrado, G.;

Rouphael, Y.; Mori, M. Assessment of Yield and Nitrate Content of Wall Rocket Grown under Diffuse-Lightor Clear-Plastic Films and Subjected to Different Nitrogen Fertilization Levels and Biostimulant Application. Horticulturae 2022, 8, 138. https:// doi.org/10.3390/horticulturae 8020138

Academic Editors: Sławomir Michałek and Marzena Błażewicz-Woźniak

Received: 31 December 2021

Accepted: 3 February 2022

Published: 6 February 2022

Publisher's Note: MDPI stays neutral with regard to jurisdictional claims in published maps and institutional affiliations.

Copyright: (c) 2022 by the authors. Licensee MDPI, Basel, Switzerland. This article is an open access article distributed under the terms and conditions of the Creative Commons Attribution (CC BY) license (https:// creativecommons.org/licenses/by/ $4.0 /)$.

\begin{abstract}
The quantity and quality of wall rocket (Diplotaxis tenuifolia L.) production are strongly influenced by the cultivation system, in particular the protected environment conditions and nitrogen fertilization. In the present research, we tested two greenhouse cover films (Film1: diffuse light; Film2: clear), to verify the effects on yield and nitrate content (a detrimental factor of quality) of rocket leaves, fertilized with optimal (N2) or sub-optimal nitrogen dose (N1), or unfertilized (N0). In addition, we combined the $\mathrm{N}$ fertilization with a biostimulant application, declared by the manufacturer as able to reduce nitrate content. Film1 provided a 36\% yield increase over Film 2 and allowed an increasing production until the $\mathrm{V}$ harvest, opposite to what was recorded under Film2, where the yield increased only until the III harvest. Additionally, biostimulant application boosted the yield ( $+40 \%)$, as well as nitrogen fertilization. Both factors had the best performance under Film1, where N1 yield was even equal to N2-Film2. The nitrate content showed a seasonal trend (lower values in spring harvests) and it was boosted by nitrogen $(1096,3696$, and $4963 \mathrm{mg} / \mathrm{kg}$ fresh weight, for N0, N1, and N2, respectively) and biostimulant application (3924 vs. $2580 \mathrm{mg} / \mathrm{kg}$ fresh weight). Therefore, the use of diffuse-light film seems useful to obtain higher yield with a halved $\mathrm{N}$ dose as well as in combination with biostimulant application, but the latter did not confirm the capacity to contain nitrate, at least for this crop and in this cultivation system.
\end{abstract}

Keywords: Diplotaxis tenuifolia L.; greenhouse conditions; plastic films properties; nitrogen rates; non-microbial biostimulant; $\mathrm{NO}_{3}$; SPAD index

\section{Introduction}

Perennial wall rocket (Diplotaxis tenuifolia L.) is widely spread across the world, especially in the Middle East and Southern Italy, where it is used mainly for fresh consumption [1]. This species is popular also in the baby leaf industry [2]. Rocket leaves have a distinct taste and good nutritional content, rich in vitamins (A, B, C, and K), iron, bioactive compounds, and proteins [3]. Despite its high nutritional value, rocket, just like many green leafy vegetables, accumulates nitrate in leaf tissues. This compound can negatevely affect product quality. An excessive dietary intake of nitrate can be harmful to human health, causing for instance, methemoglobinemia [4-6]. Therefore, the concentration of nitrate in these crops is regulated by the EU Reg. 1258/2011. Nitrates are the main supply of $\mathrm{N}$ for land plants and are essential for the biosynthesis of nucleic acids and proteins [7]. 
Their concentration in leaf tissues depends on many factors such as fertilization schemes (in particular $\mathrm{N}$ doses) $[5,8,9]$ and types of fertilizers $[5,9,10]$, but it is also influenced by N-uptake and metabolism $[4,11,12]$.

In addition, nitrogen assimilation and accumulation are strongly linked to nitrate reductase activity, a process strongly affected by light [13]. The effects of light and fertilization are opposite; the nitrate content in green plant tissues has a direct relation with $\mathrm{N}$ fertilization and inverse with light [4,5,11,14-18]. Since the light intensity varies during the season, the nitrate content also shows a seasonal behavior. Generally, it is higher in green leafy vegetables grown during the autumn-winter season than those grown during the spring-summer cycle $[16,17,19]$. However, not only the light intensity but also the type of radiation can affect nitrate accumulation. It is known that global radiation consists of direct and diffuse radiation, which is reflected or scattered sunlight due to several factors / compounds (air molecules, water vapor, clouds, dust, pollutants, forest fires, and volcanoes) [20]. Atmospheric conditions can reduce the direct radiation by $10 \%$ on clear, dry days and by $100 \%$ on overcast, cloudy days [20]. These barriers to solar radiation transmission can modify light from its natural form.

Under greenhouse conditions, the glass or plastic cover intercepts a part of solar radiation. Light conditions are different from open field conditions [21] and reduced by about $30 \%$ [22,23]. In addition, conventional materials can provide the direct distribution of light on the different leaves according to the solar angle; high level of light, as often occurs under a direct light condition, can lead to photosynthetic saturation and a decrease in light use efficiency [24]. New cover materials have been developed, such as photoselective films but also diffuse-light films, which have the characteristic to distribute the photosynthetically active radiation (PAR) in a more uniform manner to all the leaves of the canopy [25], with an overall improvement of the growth and development of the plants [26,27]. Fausey et al. [28] observed a linear relationship between the amount of light and dry mass of shoots in several perennial herbaceous species grown in greenhouses, and Hemming et al. [29] recommended the use of cover material with a minimum diffusivity of $50 \%$ and a transmittance of $90 \%$. Conditions of high diffuse radiation elicit a plant production increase as a result of a higher efficient yield per unit of PAR [30]. In these conditions, radiation comes from all the directions and can penetrate deeper into the canopy that is usually shaded, thus covering it uniformly [31] and increasing the light use efficiency and consequently yield, since the photosynthesis is the main factor influencing productivity [32]. In addition, some authors claimed that plants cultivated under diffuse light suffer fewer stress events related to water and heat $[33,34]$.

In view of a sustainable agriculture, biostimulants are finding large diffusion among farmers, both as substitutes of and in combination with chemical fertilizers. Biostimulants have different origins and characteristics (microbial or non-microbial), and approximately $75 \%$ of non-microbial biostimulants are made of seaweed extracts and microalgae, protein hydrolysates and amino acids, and plant extracts [35-38].

Considering the above-mentioned points, a possibility to reach higher yield under protected conditions could be the choice of diffuse light cover films for increasing light use efficiency; obviously, in these conditions, and especially for some crops such as green leafy vegetables, avoiding or limiting the accumulation of nitrate in leaves is not a secondary target, and it can be reached through the optimization of $\mathrm{N}$ fertilization in order to reduce $\mathrm{N}$ losses and increase the nitrogen use efficiency. The present research aimed to test two greenhouse cover films, with high or low diffuse radiation/global radiation ratios ( $\mathrm{Rd} / \mathrm{Rg})$, to verify their effects on yield and nitrate content of rocket leaves fertilized with optimal or sub-optimal nitrogen doses. In addition, we combined the nitrogen fertilization with an

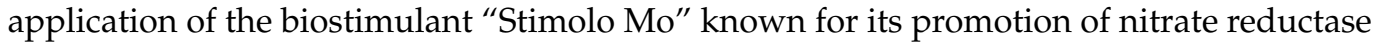
due to the fast supply of molybdenum. 


\section{Materials and Methods}

\subsection{Experimental Design, Setting, and Crop Characteristics and Management}

The experiment was carried out from autumn 2020 until spring 2021 at the experimental site of the University of Naples Federico II, Department of Agricultural Science in Portici (Naples, Italy) in pots $\left(0.38 \mathrm{~m}^{2}\right)$ located under two tunnels. The experimental design was a split-split plot that compared two different greenhouse cover plastic films as main factor, and two sub-factors made of three nitrogen rates, and two biostimulant treatments. All treatments were replicated three times for a total of 36 pots. Wild rocket (Diplotaxis tenuifolia L.) cv. 'Reset' (Maraldi Sementi Srl, Cesena, Italy) was transplanted on 8 October 2020, with a density of 18 plants per square meter and harvested 6 times: 27 November 2020, 3 February, 9 March, 8 April, 5 and 28 May 2021. This variety has green leaves with medium-sized lobes and high yield. In addition, it has a good Fusarium spp. tolerance and great growing flexibility, making it suitable to be produced in any season [39].

The soil was sandy (91\% sand, 4.5\% silt, and 4.5\% clay, USDA classification), with 253 ppm $\mathrm{P}_{2} \mathrm{O}_{5}, 490$ ppm $\mathrm{K}_{2} \mathrm{O}, 2.5 \%$ organic matter, $0.101 \%$ total nitrogen, and $\mathrm{pH}$ 7.4. During all growing cycles, water loss was calculated by the Hargreaves formula, and pots were irrigated with an amount of water equal to the evapotranspiration. No pesticide treatments were made. The dates of harvests are expressed in days after transplant (DAT) for the first cycle, and in days after previous harvest (DAPH) for all the other cycles and are reported in Table 1.

Table 1. Timing of fertilization, biostimulant application, and harvests.

\begin{tabular}{|c|c|c|c|c|c|}
\hline \multirow[t]{2}{*}{ Cycle } & \multicolumn{4}{|c|}{ Agricultural Practices (DAT/DAPH *) } & \multirow{2}{*}{$\begin{array}{c}\text { Harvest } \\
\text { DAT/DAPH * }\end{array}$} \\
\hline & Fertilization & Biostimulant 1 & Biostimulant 2 & Biostimulant 3 & \\
\hline I & 18 & 26 & 33 & 40 & 50 \\
\hline II & 7 & 14 & 21 & 30 & 68 \\
\hline III & 6 & 14 & 21 & 27 & 34 \\
\hline IV & 6 & 10 & 17 & 23 & 30 \\
\hline $\mathrm{V}$ & 4 & 8 & 14 & 19 & 27 \\
\hline VI & 3 & 5 & 11 & 17 & 23 \\
\hline
\end{tabular}

* DAT: days after transplant; DAPH: days after previous harvest (from second cycle onwards), Biostimulant 1 : first application, Biostimulant 2: second application, Biostimulant 3: third application.

\subsection{Plastic Films Properties, Nitrogen Rates, and Biostimulant Application}

The two tunnels were covered with plastic films with different optical properties. Both films were thermal films 150 microns thick. Film1 is a diffused light film ( $58 \%$ diffusivity), marketed with trade name "SUNSAVER Diff", manufactured by Ginegar Plastic Products and supplied by Polyeur Srl (Benevento, Italy). It has an anti-drip effect, an 87\% thermicity, and a window in the UV-B range (280-315 nm) with about 30\% transmissivity to UV-B radiation, and a total transmittivity (direct plus diffused components of light transmitted) in photosynthetically active radiation (PAR) of $90 \%$. Film2 is a clear plastic film, marketed with commercial name "LIRSALUX" by Lirsa Srl (Ottaviano, NA, Italy). It has an anti-drip effect, a 75\% thermicity, no transmission in the UV-B range, and a total transmittivity in PAR of $85 \%$. More details on the two films are reported in Di Mola et al. [40].

The applied nitrogen rates were 0,9 , and $18 \mathrm{~kg} \mathrm{ha}^{-1}, \mathrm{~N} 0, \mathrm{~N} 1$, and N2, respectively. Nitrogen was applied as ammonium nitrate (34\%) several times, the first 18 days after the transplant and then about 7 days after each harvest.

Regarding the biostimulation, the two treatments were: untreated and treated with the biostimulant "Stimolo Mo", hereafter Control and StMo, respectively. "Stimolo Mo", produced by Fertenia Srl (Bellizzi, SA, Italy), is an extract of alfalfa, seaweed (Ascophyllum nodosum), and molasses rich in low-molecular-weight amino acids, with $5 \%$ organic nitrogen, $3 \%$ molybdenum, and $0.1 \%$ zinc. The product is characterized by a fast penetration into the leaves, and it is mainly indicated for green leafy vegetables. It elicits crop growth, accelerating the transformation of nitric nitrogen in organic compounds (amino acids and 
proteins). As reported by the manufacturer, "Stimolo $\mathrm{Mo}^{\prime}$ promotes nitrate reductase thanks to the fast supply of molybdenum [41]. The biostimulant was applied by foliar spraying, at a dose of $3 \mathrm{~mL} / \mathrm{L}$, three times per cycle, starting from the emission of new leaves. The timing of nitrogen supply and biostimulant applications are reported in Table 1.

\subsection{Yield Measurements, Nitrate Content, SPAD Index and Color Parameters}

At each harvest, the whole aboveground part was cut for the determination of yield, which was expressed in $\mathrm{kg} \mathrm{m}^{-2}$; in addition, the number of leaves per plant and the average leaf weight were also measured. For each replicate/pot, a representative sample of leaves was oven-dried at $70{ }^{\circ} \mathrm{C}$ until reaching a constant weight both for determining the dry matter percentage and for the subsequent nitrate determination in leaves. Nitrate content was evaluated by Foss FIAstar 5000 (FOSS Italia S.r.l., Padova, Italy) continuous flow Analyzer.

At each harvest, the SPAD index and the CIELAB (Commission international de l'eclairage) color parameters $\left(L^{*} ; a^{*} ; b^{*}\right)$ were measured on ten undamaged fully expanded leaves with a chlorophyll meter SPAD-502 (Konica Minolta, Tokyo, Japan) and a Minolta CR-300 Chroma Meter (Minolta Camera Co. Ltd., Osaka, Japan), respectively.

\subsection{Temperature Measurements and Soil Nitrate and Total Nitrogen Analysis}

The air temperature was continuously monitored by a weahther station (Vantage Pro2, Davis Instruments) and the data were reported as hourly means; probes were located over the canopy at $20 \mathrm{~cm}$ and distributed randomly across the experiment.

At each harvest, soil was sampled to determine nitrate content by Foss FIAstar 5000 (FOSS Italia S.r.l., Padova, Italy) continuous flow analyzer, and total nitrogen content was measured according to the Kjeldhal method [42].

\subsection{Statistical Analysis}

All data were subjected to 4-way analysis of variance (ANOVA) with the SPSS software package (SPSS version 22, Chicago, IL, USA). The means were separated using Tukey's test at $p \leq 0.05$.

\section{Results}

\subsection{Envrionmental Conditions: Air Temperatures and Soil Nitrogen Content}

The trend of mean temperatures under both films was typical for Mediterranean areas. The mean value of all growth periods was 16.3 and $16.1^{\circ} \mathrm{C}$ for clear and diffuse-light film, respectively (Figure 1). However, we recorded differences in the thermal behavior of films in the different seasons of the year. During the autumn months (second ten-days of October and second ten-days of December), under Film 1 the mean temperature was $15.6{ }^{\circ} \mathrm{C}$ vs. $15.4^{\circ} \mathrm{C}$ of Film2. Similarly, in the winter months (December-March) the difference between the two films was $0.2^{\circ} \mathrm{C}\left(14.0^{\circ} \mathrm{C}\right.$ and $13.8^{\circ} \mathrm{C}$ for Film1 and Film2, respectively). The trend was inverted in the spring months (March to the last harvest), where under the clear film the mean temperature was $20.3{ }^{\circ} \mathrm{C}$ while under diffuse-light film was $19.3{ }^{\circ} \mathrm{C}$.

No interaction was noted for all the tested factors (cover film, fertilization, biostimulant) (Table 2). During the six harvests, the nitrate and total nitrogen content in the soil were significantly influenced only by the main effect of fertilization and biostimulant application (Table 2). Both parameters increased when nitrogen rates increased but in a different way. Specifically, for nitrate content, the increase over not fertilized was more than three- and four-fold, for N1 and N2, respectively. Instead, for total nitrogen, no differences were found between N0 and N1, while N2 elicited a 9.6\% increase over the mean value of the other two treatments. Regarding the biostimulant application, for both parameters, biostimulant caused an increase of $52.1 \%$ and $3.8 \%$ for nitrate and $\mathrm{N}$ total, respectively. 


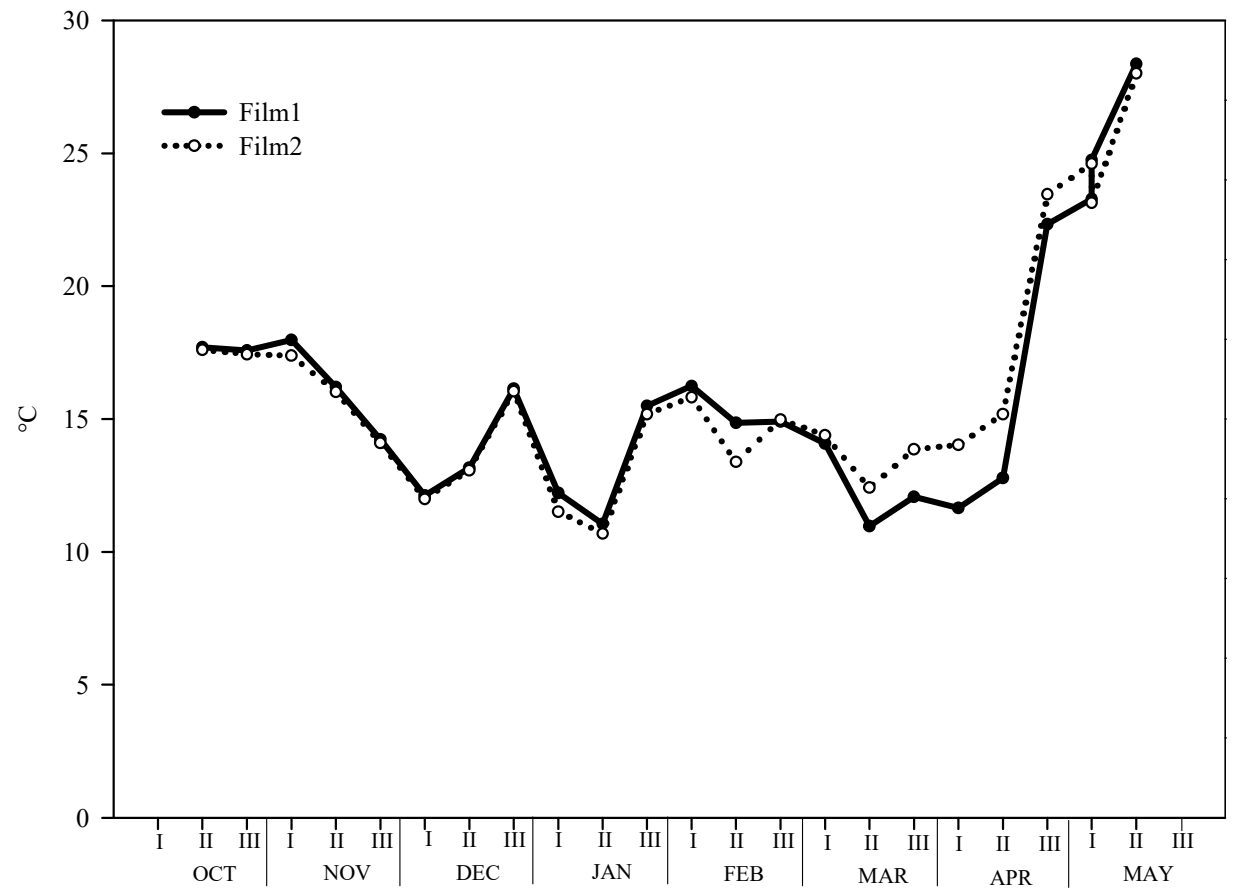

Figure 1. Trend of average temperature during the whole growing period under the two greenhouse plastic films (Film1: diffuse-light film; Film2: clear film).

Table 2. $\mathrm{N}-\mathrm{NO}_{3}$ content and total nitrogen of soil as affected by mean effects of nitrogen fertilization dose (N0: not fertilized; N1: fertilized with $9 \mathrm{~kg} \mathrm{~N} \mathrm{ha}^{-1}$; N2: fertilized with $18 \mathrm{~kg} \mathrm{~N} \mathrm{ha}^{-1}$ ) and by biostimulant application (Control: untreated; StMo: treated with biostimulant).

\begin{tabular}{ccc}
\hline Treatments & $\begin{array}{c}\mathbf{N}-\mathbf{N O}_{3} \\
\mathbf{p p m}\end{array}$ & $\begin{array}{c}\text { Total N } \\
\%\end{array}$ \\
\hline N0 & $56.3 \mathrm{c}$ & $0.105 \mathrm{~b}$ \\
N1 & $97.2 \mathrm{~b}$ & $0.103 \mathrm{~b}$ \\
N2 & $173.2 \mathrm{a}$ & $0.114 \mathrm{a}$ \\
Control & $80.7 \mathrm{~b}$ & $0.105 \mathrm{~b}$ \\
StMo & $137.1 \mathrm{a}$ & $0.109 \mathrm{a}$ \\
Plastic Film (P) & $\mathrm{ns}$ & $\mathrm{ns}$ \\
Biostimulant (B) & 0.001 & 0.001 \\
Fertilization (F) & 0.001 & 0.001 \\
Harvest (H) & $\mathrm{ns}$ & $\mathrm{ns}$ \\
\hline
\end{tabular}

ns: not significant; different letters within each column indicate significant differences at $p \leq 0.05$. (Tukey's test).

\subsection{Statistical Results of Yield and Crop Parameters}

The main effect of the experimental factors was always significant for all parameters except for brightness ( $\left.\mathrm{L}^{*}\right)$ (plastic film), $\mathrm{a}^{*}$ (biostimulant and fertilization) and $\mathrm{b}^{*}$ (harvest) (Table 3). The interaction of fourth degree was not significant, whereas the third-degree interaction was only significant for nitrate $(\mathrm{P} \times \mathrm{B} \times \mathrm{H}$ and $\mathrm{B} \times \mathrm{F} \times \mathrm{H})$. The interaction $\mathrm{P} \times$ $\mathrm{B}$ was significant for all parameters except for nitrate; $\mathrm{P} \times \mathrm{F}$ was significant only for yield, leaf number, and leaf weight average; $\mathrm{P} \times \mathrm{H}$ was significant for yield and nitrate; $\mathrm{B} \times \mathrm{F}$ was significant for leaf dry matter and number, $\mathrm{L}^{*}, \mathrm{~b}^{*}$, SPAD index and nitrate; $\mathrm{B} \times \mathrm{H}$ was significant for yield and nitrate; and finally, $\mathrm{F} \times \mathrm{H}$ was significant for the yield, leaf DM and $\mathrm{nb}$ and nitrate. 
Table 3. Analysis of variance of yield and its parameters, SPAD index, color parameters, and nitrate content: significance of main factors and interactions.

\begin{tabular}{|c|c|c|c|c|c|c|c|c|c|}
\hline Significance & Yield & $\begin{array}{c}\text { Leaf } \\
\text { DM }\end{array}$ & $\begin{array}{c}\text { Leaf } \\
\mathrm{Nb}\end{array}$ & $\begin{array}{c}\text { Leaf } \\
\text { AW }\end{array}$ & $\mathbf{L}^{*}$ & $a^{*}$ & $\mathbf{b}^{*}$ & SPAD & Nitrate \\
\hline Plastic films (P) & 0.01 & 0.01 & 0.01 & 0.01 & ns & 0.01 & 0.01 & 0.01 & ns \\
\hline Biostimulant (B) & 0.01 & 0.01 & 0.01 & 0.01 & 0.01 & ns & 0.01 & 0.05 & 0.01 \\
\hline Fertilization (F) & 0.01 & 0.01 & 0.01 & 0.01 & 0.01 & ns & 0.01 & 0.01 & 0.01 \\
\hline Harvest (H) & 0.01 & 0.01 & 0.01 & 0.01 & ns & 0.01 & ns & 0.01 & 0.01 \\
\hline $\mathrm{P} \times \mathrm{B}$ & 0.01 & 0.01 & 0.01 & 0.05 & 0.01 & 0.01 & 0.01 & 0.05 & ns \\
\hline $\mathrm{P} \times \mathrm{F}$ & 0.01 & ns & 0.05 & 0.01 & $\mathrm{~ns}$ & ns & ns & ns & ns \\
\hline $\mathrm{P} \times \mathrm{H}$ & 0.01 & ns & ns & ns & ns & ns & ns & ns & 0.01 \\
\hline $\mathrm{B} \times \mathrm{F}$ & ns & 0.01 & 0.05 & ns & 0.01 & ns & 0.01 & 0.01 & 0.01 \\
\hline $\mathrm{B} \times \mathrm{H}$ & 0.01 & ns & ns & ns & ns & ns & ns & ns & 0.01 \\
\hline $\mathrm{F} \times \mathrm{H}$ & 0.01 & 0.01 & 0.01 & ns & ns & ns & ns & ns & 0.01 \\
\hline $\mathrm{P} \times \mathrm{B} \times \mathrm{F}$ & ns & ns & ns & ns & ns & ns & ns & ns & ns \\
\hline $\mathrm{P} \times \mathrm{B} \times \mathrm{H}$ & ns & ns & ns & ns & ns & ns & ns & ns & 0.01 \\
\hline $\mathrm{P} \times \mathrm{F} \times \mathrm{H}$ & ns & ns & ns & ns & ns & ns & ns & ns & ns \\
\hline $\mathrm{B} \times \mathrm{F} \times \mathrm{H}$ & ns & ns & ns & ns & ns & ns & ns & ns & 0.01 \\
\hline $\mathrm{P} \times \mathrm{B} \times \mathrm{F} \times \mathrm{H}$ & ns & ns & ns & ns & ns & ns & ns & ns & ns \\
\hline
\end{tabular}

DM: dry matter; $\mathrm{Nb}$ : number; $\mathrm{AW}$ : average weight, ns: non-significant. n.s: non-significant, and significant differences at $p \leq 0.05$ or 0.01 . (Tukey's test).

\subsection{Yield as Affected by the Experimental Factors}

The average yield of rocket was $0.75 \mathrm{~kg} \mathrm{~m}^{-2}$, but the two greenhouse cover plastic films strongly affected the productive response of this crop (Figure 2). The mean value of the diffuse-light film (Film1) was higher than that of clear film (Film2): $0.86 \mathrm{vs} .0 .63 \mathrm{~kg} \mathrm{~m}^{-2}$, respectively, with a $36.5 \%$ increase. Under the two films, the trend of the six harvests was slightly different. Under Film1, the yield increased gradually over the growing period, and the last three harvests were not significantly different). Instead, under Film2, the first two harvests were not significantly different, and starting the third harvest, the marketable yield was not significantly different from the rest and reached a mean value $\left(0.74 \mathrm{~kg} \mathrm{~m}^{-2}\right)$ resembling that of the third harvest under Film1 $\left(0.79 \mathrm{~kg} \mathrm{~m}^{-2}\right)$.

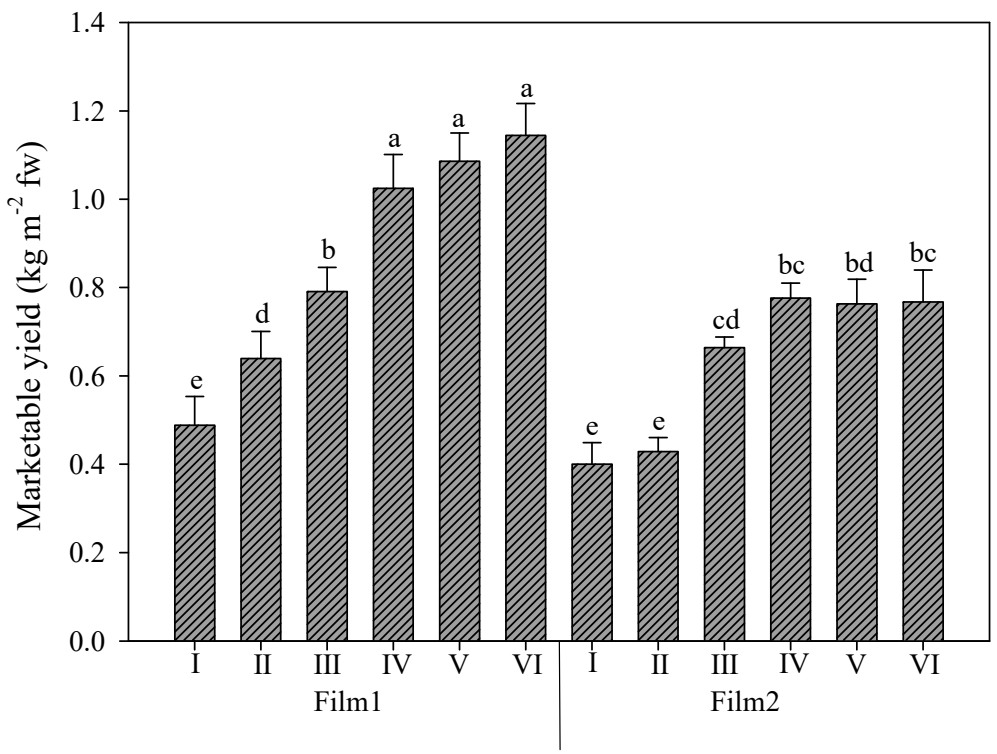

Figure 2. Rocket yield as affected by greenhouse plastic films (Film1: diffuse-light film; Film2: clear film) and number of harvests. Vertical bars indicate standard error; different letters indicate statistical difference according to Tukey's test $(p \leq 0.01)$. 
In Figure 3, the interaction between nitrogen rates and harvests is reported. The effect of nitrogen fertilization over the cycles was particularly evident. The mean value of marketable yield was $0.37,0.82$, and $0.99 \mathrm{~kg} \mathrm{~m}^{-2}$ for $\mathrm{N} 0, \mathrm{~N} 1$, and $\mathrm{N} 2$, respectively. Additionally, in this case, the trend of the six harvest was different under the three $\mathrm{N}$ rates. For unfertilized plants, no differences between the harvests were recorded. Instead, for plants fertilized with half of the optimal dose, the yield significantly increased until the fourth harvest, which was not significantly different from the fifth and sixth ones. Finally, for plants fertilized with full $\mathrm{N}$ dose, the yield increased gradually until the last harvest, with the fourth and fifth harvest exhibiting no differences.

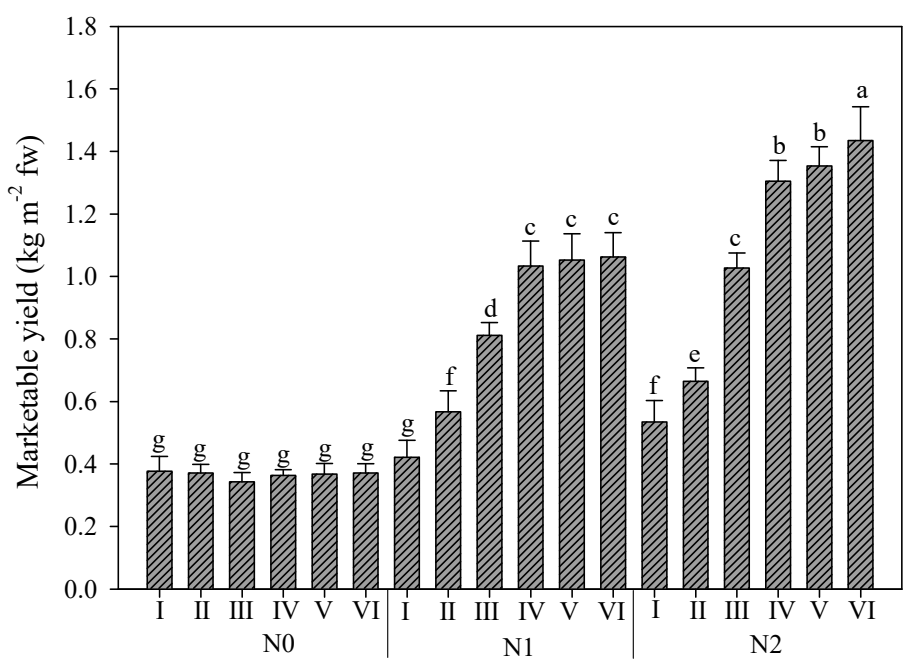

Figure 3. Rocket yield as affected by nitrogen fertilization dose (N0: not fertilized; N1: fertilized with $9 \mathrm{~kg} \mathrm{~N} \mathrm{ha}^{-1}$; N2: fertilized with $18 \mathrm{~kg} \mathrm{~N} \mathrm{ha}^{-1}$ ) and number of harvests. Vertical bars indicate standard error; different letters indicate statistical difference according to Tukey's test $(p \leq 0.01)$.

The effect of the used biostimulant was marked. The plants treated with "Stimolo Mo" had a boosted yield reaching values almost $40 \%$ higher than control plants $(0.91$ vs. $0.65 \mathrm{~kg} \mathrm{~m}^{-2}$ ) (Figure 4). Both treated and untreated plants reached a plateau of marketable yield starting the IV harvest, but the biostimulant significantly increased the yield value of the second harvest compared to the first one, contrarily to what occurred in untreated plants.

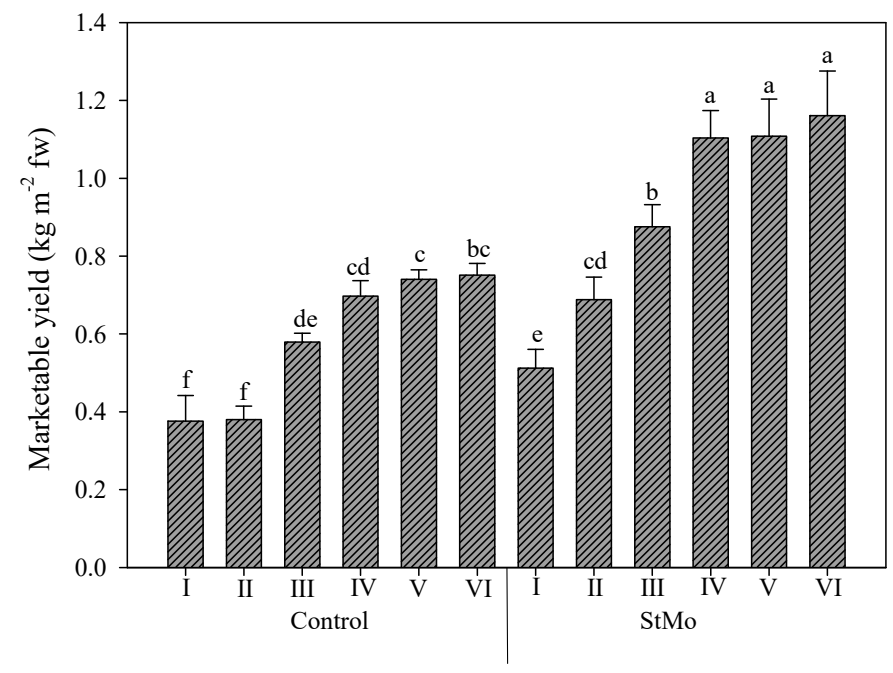

Figure 4. Rocket yield as affected by biostimulant application (Control: untreated; StMo: treated with biostimulant) and number of harvests. Vertical bars indicate standard error; different letters indicate statistical difference according to Tukey's test $(p \leq 0.01)$. 
The interaction between greenhouse cover plastic films and nitrogen doses is reported in Figure 5. Nitrogen fertilization obviously assured a yield increase, with significant differences between the two fertilizations (N1 and N2); both doses boosted the yield better under Film1; instead, no differences were found between the unfertilized treatments under the two films. The percentage increases caused by diffuse-light film were 35.8, 47.6, and $28.0 \%$ for N0, N1, and N2, respectively.

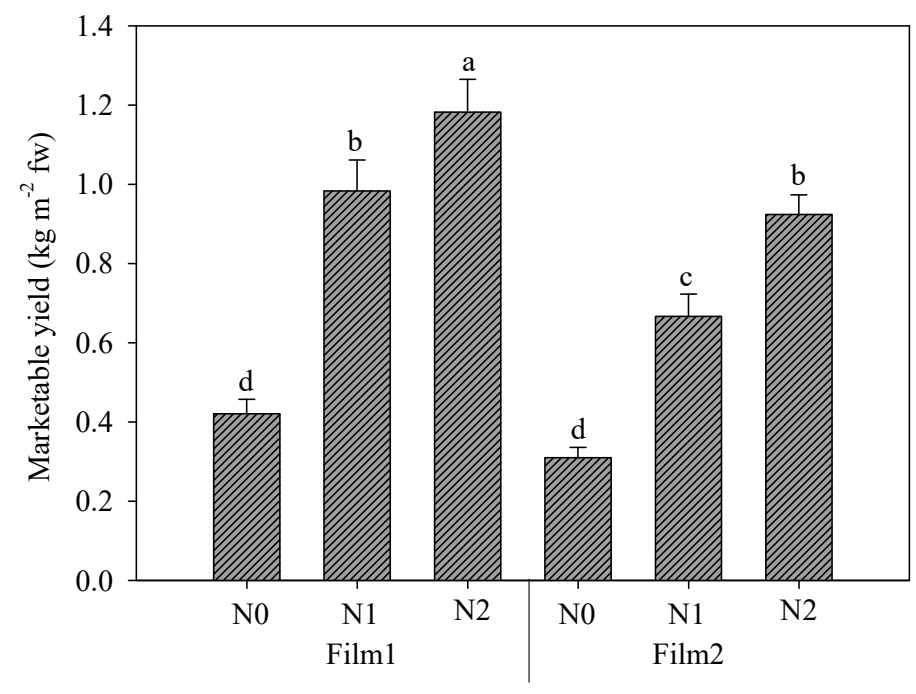

Figure 5. Rocket yield as affected by greenhouse plastic films (Film1: diffuse-light film; Film2: clear film) and nitrogen fertilization dose (N0: not fertilized; N1: fertilized with $9 \mathrm{~kg} \mathrm{~N}^{-1}$; N2: fertilized with $18 \mathrm{~kg} \mathrm{~N} \mathrm{ha}^{-1}$ ). Vertical bars indicate standard error; different letters indicate statistical difference according to Tukey's test $(p \leq 0.01)$.

Finally, the interaction between plastic films and biostimulant application again highlighted the effect of diffuse-light film (Figure 6). Both Control plants and StMo plants under Film1 reached significantly higher yield values than the corresponding treatments under Film2, +29.1 and $+40.9 \%$, respectively. Interestingly, the Control plants grown under diffuse-light film reached yield levels not significantly different from treated plants under clear film.

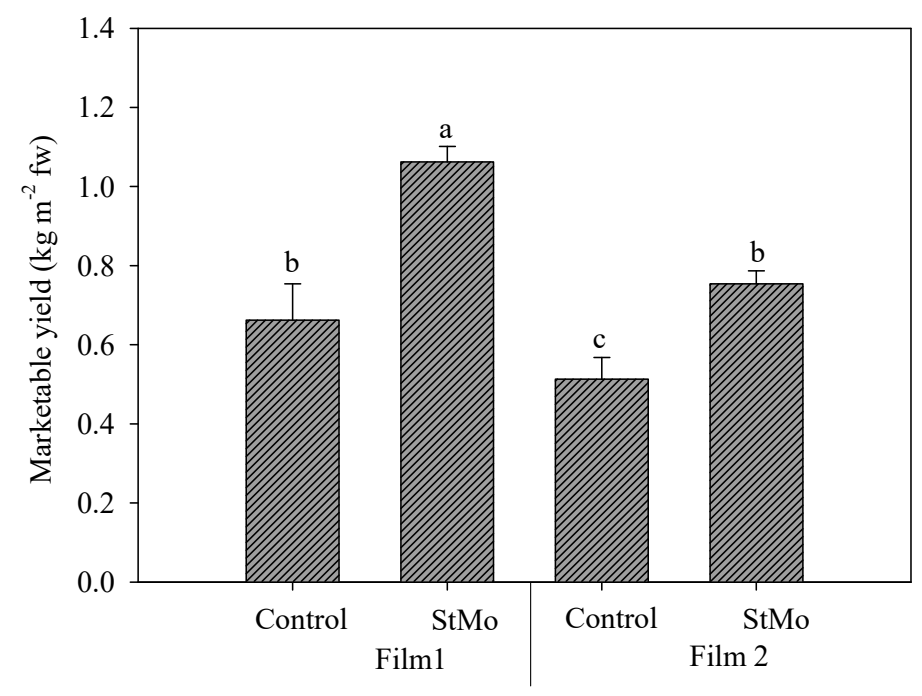

Figure 6. Rocket yield as affected by greenhouse plastic films (Film1: diffuse-light film; Film2: clear film) and biostimulant application (Control: untreated; StMo: treated with biostimulant). Vertical bars indicate standard error; different letters indicate statistical difference according to Tukey's test $(p \leq 0.01)$. 


\subsection{Yield Parameters}

The effects of the significant second-degree interactions on yield parameters are reported in Table 4. For the number of leaves and leaf average weight, the diffuse-light film determined higher values than clear film, with an increase of 20.2 and $7.5 \%$, respectively. However, the treatment with Stimolo-Mo further boosted the two parameters under both films, but with a stronger effect under diffuse-light film $(+32.8 \%$ and $15.0 \%$, and $+19.1 \%$ and $+10.5 \%$ for the number of leaves per plant and average leaf weight, under diffuse-light film and clear film, respectively). For both parameters, the Control plants grown under diffuse film were not different from the treated plants under clear film but also from Control plants grown under clear film. Regarding the dry matter percentage of leaves, the trend is inverted; indeed, the value was higher under clear film (13.1\% vs. $12.2 \%)$ and in Control plants with respect to treated plants $(+22.4 \%)$.

Table 4. Leaf dry matter, leaf number, leaf weight average of rocket as affected by the following interactions: greenhouse plastic films (Film1: diffuse-light film; Film2: clear film) and biostimulant application (Control: untreated; StMo: treated with biostimulant); greenhouse plastic films and nitrogen fertilization dose (N0: not fertilized; N1: fertilized with $9 \mathrm{~kg} \mathrm{~N}$ ha $^{-1}$; N2: fertilized with $18 \mathrm{~kg} \mathrm{~N} \mathrm{ha}^{-1}$ ); biostimulant application and nitrogen fertilization dose.

\begin{tabular}{|c|c|c|c|c|}
\hline \multicolumn{2}{|c|}{ Treatments } & \multicolumn{3}{|c|}{ Leaves } \\
\hline & & Dry Matter (\%) & $\mathrm{N}^{\circ}$ Plant $^{-1}$ & g Leaf $^{-1}$ \\
\hline \multirow[t]{2}{*}{ Film1 } & StMo & $10.7 \mathrm{~b}$ & 292.9 a & $0.23 \mathrm{a}$ \\
\hline & Control & $13.8 \mathrm{a}$ & $220.6 \mathrm{bc}$ & $0.20 \mathrm{ab}$ \\
\hline \multirow[t]{2}{*}{ Film2 } & StMo & $12.1 \mathrm{ab}$ & $232.3 \mathrm{~b}$ & $0.21 \mathrm{a}$ \\
\hline & Control & $14.1 \mathrm{a}$ & $195.0 \mathrm{c}$ & $0.19 \mathrm{~b}$ \\
\hline \multirow[t]{3}{*}{ Film1 } & No & $14.4 \mathrm{~ns}$ & $180.6 \mathrm{bc}$ & $0.15 \mathrm{c}$ \\
\hline & N1 & $11.3 \mathrm{~ns}$ & $282.4 \mathrm{a}$ & $0.24 \mathrm{ab}$ \\
\hline & N2 & $10.9 \mathrm{~ns}$ & $307.2 \mathrm{a}$ & $0.26 \mathrm{a}$ \\
\hline \multirow[t]{3}{*}{ Film2 } & No & $15.0 \mathrm{~ns}$ & $143.9 \mathrm{c}$ & $0.16 \mathrm{c}$ \\
\hline & N1 & $12.6 \mathrm{~ns}$ & $219.0 \mathrm{~b}$ & $0.21 \mathrm{~b}$ \\
\hline & N2 & $11.7 \mathrm{~ns}$ & $278.1 \mathrm{a}$ & $0.23 \mathrm{ab}$ \\
\hline \multirow[t]{3}{*}{ Control } & No & $16.5 \mathrm{a}$ & $126.4 \mathrm{~d}$ & $0.14 \mathrm{~ns}$ \\
\hline & N1 & $13.1 \mathrm{~b}$ & $232.2 \mathrm{bc}$ & $0.21 \mathrm{~ns}$ \\
\hline & N2 & $12.3 \mathrm{bc}$ & $264.8 \mathrm{~b}$ & $0.24 \mathrm{~ns}$ \\
\hline \multirow[t]{3}{*}{ StMo } & No & $13.0 \mathrm{~b}$ & $198.1 \mathrm{c}$ & $0.17 \mathrm{~ns}$ \\
\hline & N1 & $10.9 \mathrm{~cd}$ & $269.2 \mathrm{~b}$ & $0.23 \mathrm{~ns}$ \\
\hline & N2 & $10.3 \mathrm{~d}$ & $320.5 \mathrm{a}$ & $0.25 \mathrm{~ns}$ \\
\hline
\end{tabular}

ns: non-significant. Different letters within each column indicate significant differences according to Tukey's test $p \leq 0.05$.

The interaction between the greenhouse cover films and nitrogen dose did not have a significant effect on leaves DM; for the other two parameters, under diffuse-light film, both nitrogen doses had a similar effect (no significant differences), which was not the case under clear film where the N2 dose engendered significantly higher values for the number of leaves per plant (Table 4).

Finally, the interaction between biostimulant and nitrogen dose did not significantly affect the average weight of leaves but only the other two parameters in an opposite way (Table 4). Indeed, as already reported, the DM was higher in Control plants than treated plants, contrary to the number of leaves ( $+26.4 \%$ over Control plants). In addition, the DM was significantly higher in N0 plants and untreated plants, which, instead, showed the lowest number of leaves per plant, different from all the other treatments.

The interactions between nitrogen doses and the harvests on yield parameters are reported in Table 5. The average leaf weight was not affected by both factors. The number of leaves per plant increased with the increment of nitrogen dose: 162.3, 250.7, and 292.7 for N0, $\mathrm{N} 1$, and N2, respectively. In addition, for fertilized plants, the number of leaves increased over the harvests, reaching the highest values at the last harvest; instead, for unfertilized 
plants, no significant differences were highlighted between the first five harvests. Finally, the dry matter percentage of leaves was lower in the two fertilized treatments $(11.7 \%$ vs. $14.7 \%$ of Control plants). In addition, in N0 plants, the DM increased over the harvests, reaching the highest value at harvests IV and VI. In N1 and N2, only the first harvest was significantly lower than all the other harvests except for harvest VI of the N2 (Table 5).

Table 5. Leaf dry matter, leaf number, leaf weight average of rocket as affected by interaction between nitrogen fertilization dose (N0: not fertilized; N1: fertilized with $9 \mathrm{~kg} \mathrm{~N}^{-1}$; $\mathrm{N} 2$ : fertilized with $18 \mathrm{~kg} \mathrm{~N} \mathrm{ha}^{-1}$ ) and number of harvests.

\begin{tabular}{ccccc}
\hline & Treatments & Deaves & \\
& & Dry Matter (\%) & $\mathbf{N}^{\circ}$ Plant $^{-1}$ & g Leaf $^{-1}$ \\
\hline N0 & I & $11.8 \mathrm{fh}$ & $160.7 \mathrm{~lm}$ & $0.19 \mathrm{~ns}$ \\
& II & $13.3 \mathrm{~cd}$ & $140.6 \mathrm{~m}$ & $0.19 \mathrm{~ns}$ \\
& III & $14.1 \mathrm{c}$ & $153.2 \mathrm{~lm}$ & $0.16 \mathrm{~ns}$ \\
& IV & $16.9 \mathrm{a}$ & $137.9 \mathrm{~m}$ & $0.17 \mathrm{~ns}$ \\
& V & $15.5 \mathrm{~b}$ & $144.2 \mathrm{~m}$ & $0.14 \mathrm{~ns}$ \\
N1 & $16.8 \mathrm{a}$ & $237.1 \mathrm{fg}$ & $0.09 \mathrm{~ns}$ \\
& VI & $10.2 \mathrm{i}$ & $182.6 \mathrm{hi}$ & $0.24 \mathrm{~ns}$ \\
& I & $12.9 \mathrm{de}$ & $194.5 \mathrm{hi}$ & $0.23 \mathrm{~ns}$ \\
& II & $11.9 \mathrm{eh}$ & $249.4 \mathrm{ef}$ & $0.24 \mathrm{~ns}$ \\
& III & $11.6 \mathrm{gh}$ & $250.7 \mathrm{ef}$ & $0.25 \mathrm{~ns}$ \\
& IV & $12.3 \mathrm{dg}$ & $270.2 \mathrm{de}$ & $0.22 \mathrm{~ns}$ \\
& V & $12.8 \mathrm{df}$ & $356.7 \mathrm{~b}$ & $0.16 \mathrm{~ns}$ \\
& VI & $10.0 \mathrm{i}$ & $177.9 \mathrm{il}$ & $0.26 \mathrm{~ns}$ \\
& I & $11.8 \mathrm{gh}$ & $211.7 \mathrm{gh}$ & $0.26 \mathrm{~ns}$ \\
& II & $11.7 \mathrm{gh}$ & $297.1 \mathrm{~cd}$ & $0.27 \mathrm{~ns}$ \\
& III & $11.4 \mathrm{gh}$ & $312.3 \mathrm{c}$ & $0.27 \mathrm{~ns}$ \\
& IV & $12.1 \mathrm{eg}$ & $350.2 \mathrm{~b}$ & $0.22 \mathrm{~ns}$ \\
& V & $11.0 \mathrm{hi}$ & $406.8 \mathrm{a}$ & $0.19 \mathrm{~ns}$ \\
\hline
\end{tabular}

ns: non-significant. Different letters within each column indicate significant differences according to Tukey's test $p \leq 0.05$.

\subsection{Nitrate Content, SPAD Index, and Color Parameters}

For the CIELAB color parameters and the SPAD index, the data regarding the interactions are reported in Table 6.

Table 6. Color parameters $\left(\mathrm{L}^{*}, \mathrm{a}^{*}, \mathrm{~b}^{*}\right)$ and SPAD index as affected by the following interactions: greenhouse plastic films (Film1: diffuse-light film; Film2: clear film) and biostimulant application (Control: untreated; StMo: treated with biostimulant); biostimulant application and nitrogen fertilization dose (N0: not fertilized; N1: fertilized with $9 \mathrm{~kg} \mathrm{~N} \mathrm{ha}^{-1}$; $\mathrm{N} 2$ : fertilized with $18 \mathrm{~kg} \mathrm{~N}^{-1}$ ).

\begin{tabular}{cccccc}
\hline \multicolumn{2}{c}{ Treatments } & $\mathbf{L}^{*}$ & $\mathbf{a}^{*}$ & $\mathbf{b}^{*}$ & SPAD \\
\hline \multirow{2}{*}{ Film1 } & Control & $41.5 \mathrm{a}$ & $-7.31 \mathrm{a}$ & $18.2 \mathrm{a}$ & $39.5 \mathrm{c}$ \\
& StMo & $40.4 \mathrm{~b}$ & $-7.13 \mathrm{ab}$ & $17.5 \mathrm{ab}$ & $43.0 \mathrm{a}$ \\
\multirow{2}{*}{ Film2 } & Control & $41.6 \mathrm{a}$ & $-6.76 \mathrm{c}$ & $17.3 \mathrm{~b}$ & $38.8 \mathrm{c}$ \\
& StMo & $41.4 \mathrm{a}$ & $-6.98 \mathrm{bc}$ & $17.5 \mathrm{ab}$ & $42.0 \mathrm{~b}$ \\
\hline \multirow{2}{*}{ Control } & $\mathrm{N} 0$ & $42.3 \mathrm{a}$ & $-7.05 \mathrm{~ns}$ & $19.0 \mathrm{a}$ & $33.5 \mathrm{e}$ \\
& $\mathrm{N} 1$ & $41.2 \mathrm{~b}$ & $-6.99 \mathrm{~ns}$ & $17.3 \mathrm{bc}$ & $40.6 \mathrm{c}$ \\
\multirow{2}{*}{ StMo } & $\mathrm{N} 2$ & $41.2 \mathrm{~b}$ & $-7.06 \mathrm{~ns}$ & $17.0 \mathrm{c}$ & $43.3 \mathrm{~d}$ \\
& $\mathrm{~N} 0$ & $41.0 \mathrm{~b}$ & $-7.12 \mathrm{~ns}$ & $18.0 \mathrm{~b}$ & $38.4 \mathrm{~d}$ \\
& $\mathrm{~N} 1$ & $40.9 \mathrm{~b}$ & $-7.00 \mathrm{~ns}$ & $17.5 \mathrm{bc}$ & $43.3 \mathrm{~b}$ \\
& $\mathrm{~N} 2$ & $40.8 \mathrm{~b}$ & $-7.03 \mathrm{~ns}$ & $17.1 \mathrm{bc}$ & $45.7 \mathrm{a}$
\end{tabular}

ns: non-significant. Different letters within each column indicate significant differences according to Tukey's test $p \leq 0.05$.

For brightness, only the plants of the treatment diffuse-light film $\times$ StMo were significantly lower than the other three treatments. The other two color parameters were not 
affected by the interaction plastic films $\times$ biostimulant application. $\mathrm{a}^{*}$ and $\mathrm{b}^{*}$ values of Control plants were higher under diffuse-light film compared to Control under clear film. Finally, the treatment with biostimulant significantly elicited the SPAD index under both films (Table 6).

Considering the interaction between the biostimulant application and nitrogen rates, $\mathrm{L}^{*}$ resulted higher in Control $\times \mathrm{N} 0$ plants, while all other treatments were equal. $\mathrm{b}^{*}$ also showed the highest value in untreated and unfertilized plants. Finally, for the SPAD index, the highest value was recorded in plants sprayed with "Stimolo-Mo" and fertilized with optimal nitrogen dose, while the lowest values was registered in Control $\times$ N0 plants (Table 6).

The successive harvest significantly affected only the a* color parameter and the SPAD index; the first showed the higher values (greener) in the first and third harvests (Table 7). The SPAD index highlighted the lowest value in the first harvest, which was different from all other treatments; from the second harvest, the values fluctuated and reached the highest value in the fourth harvest, which was significantly different from all the others, except the second (Table 7).

Table 7. Color parameters $\left(\mathrm{L}^{*}, \mathrm{a}^{*}, \mathrm{~b}^{*}\right)$ and SPAD index as affected by the number of harvests.

\begin{tabular}{ccccc}
\hline Treatments & $\mathbf{L}^{*}$ & $\mathbf{a}^{*}$ & $\mathbf{b}^{*}$ & SPAD \\
\hline I & $41.1 \mathrm{~ns}$ & $-7.64 \mathrm{a}$ & $17.8 \mathrm{~ns}$ & $35.3 \mathrm{e}$ \\
II & $41.2 \mathrm{~ns}$ & $-7.27 \mathrm{ab}$ & $17.4 \mathrm{~ns}$ & $42.9 \mathrm{ab}$ \\
III & $41.5 \mathrm{~ns}$ & $-7.57 \mathrm{a}$ & $17.9 \mathrm{~ns}$ & $41.8 \mathrm{c}$ \\
IV & $41.0 \mathrm{~ns}$ & $-6.75 \mathrm{bc}$ & $17.6 \mathrm{~ns}$ & $43.5 \mathrm{a}$ \\
V & $41.1 \mathrm{~ns}$ & $-6.24 \mathrm{c}$ & $17.2 \mathrm{~ns}$ & $41.9 \mathrm{bc}$ \\
VI & $41.6 \mathrm{~ns}$ & $-6.79 \mathrm{bc}$ & $17.8 \mathrm{~ns}$ & $39.5 \mathrm{~d}$
\end{tabular}

ns: non-significant. Different letters within each column indicate significant differences according to Tukey's test $p \leq 0.05$.

In Figure 7, the nitrate content in rocket leaves grown under the two different greenhouse plastic films and treated or not with biostimulant along the six harvests is reported. Nitrate mean value was slightly higher under diffuse-light film (3333.7 vs. 3170.5 ppm of clear film). The application of biostimulant increased the nitrate content in leaves (3924.2 vs. $2580.0 \mathrm{ppm}$ of untreated plants) but the effect of biostimulant application was higher than that of the films, indeed the higher accumulation of nitrate in rocket leaves was recorded in most of the treated plants. The nitrate content along the six harvests showed a fluctuating trend especially under the clear film. The second harvest of untreated plants under both films manifested the lowest accumulation of nitrate among all treatments. For treated plants, a different behavior was observed under both films, where the diffuse-light film caused the lowest value in the last harvest, while under the clear film, it was not different from the second harvest (Figure 7). Irrespective of plastic films and biostimulant application, the highest values of nitrate content were observed at the third harvest (except for StMo $\times$ diffuse film: first and fourth harvest and Control $\times$ clear film: first harvest). Noting that, the nitrate content decreased repeatedly after the third harvest. 


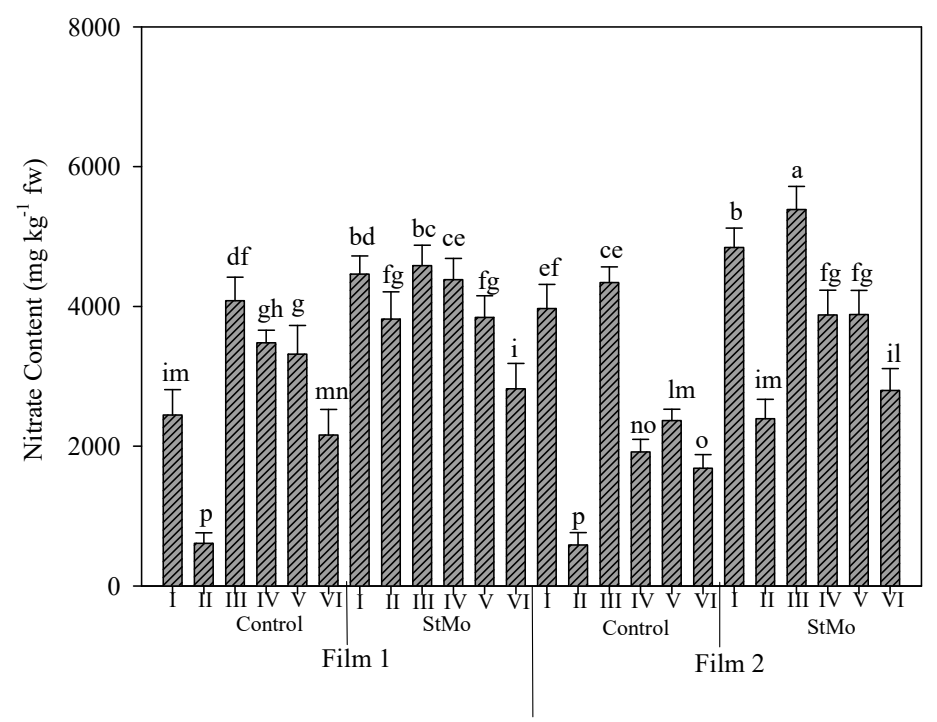

Figure 7. Nitrate content of rocket leaves as affected by greenhouse plastic films (Film1: diffuse-light film; Film2: clear film), biostimulant application (Control: untreated; StMo: treated with biostimulant) and number of harvests. Vertical bars indicate standard error; different letters indicate statistical difference according to Tukey's test $(p \leq 0.01)$.

The interaction of biostimulant application, the nitrogen rates, and the number of harvests on nitrate content is reported in Figure 8. As expected, the lowest values of nitrate content were observed in unfertilized and untreated plants ( 459.6 vs. $3810.6 \mathrm{ppm}$, mean value of all the treatments), with only plants of the first harvest registering $2200 \mathrm{ppm}$. In fact, the nitrate content decreased in these plants already at the second harvest; however, in those sprayed with biostimulant, this decrease was gradual. Additionally, for fertilized plants, a gradual decrease in nitrate content was recorded starting the third harvest. The nitrate content obviously increased with the increment of N levels: 1096, 3696, and 4963 ppm for N0, N1, and N2, respectively. Irrespective of nitrogen rates and harvests, biostimulant application determined a 52\% increase with respect to untreated plants (Figure 8).

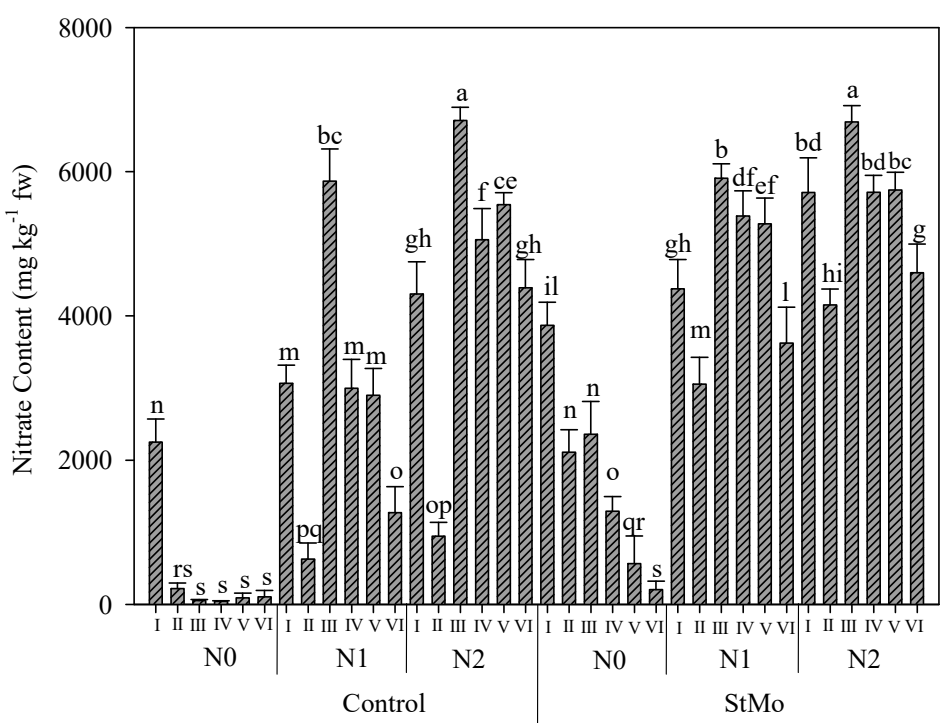

Figure 8. Nitrate content of rocket leaves as affected by biostimulant application (Control: untreated; StMo: treated with biostimulant), nitrogen fertilization dose (N0: not fertilized; N1: fertilized with $9 \mathrm{~kg} \mathrm{~N} \mathrm{ha}{ }^{-1}$; N2: fertilized with $18 \mathrm{~kg} \mathrm{~N} \mathrm{ha}^{-1}$ ) and number of harvests. Vertical bars indicate standard error; different letters indicate statistical difference according to Tukey's test $(p \leq 0.01)$. 


\section{Discussion}

Rocket is predominantly cultivated under a protected condition and nitrogen fertilization is largely used to obtain higher production and longer harvest periods. However, the environmentalconditions affect not only the yield but also the product quality. In the present research, we wanted to test two greenhouse plastic cover films with different optical properties and three nitrogen fertilization rates (an optimal dose, half of the optimal dose, and no fertilization). The reduction in nitrogen dose and the application of biostimulant was foreseen from the perspective of sustainable agriculture.

The two plastic films determined a different micro-climate because of different transmissivity and thermicity. Light intensity under these films was measured in a previous study on spinach grown in the January-March period, which indicated a higher light intensity under the diffuse-light film [40]. In addition, temperature conditions under the two films were also different based on the season. Indeed, during the autumn-winter months (October-March), the mean temperature of diffuse-light film was $14.7^{\circ} \mathrm{C}$ vs. $14.5^{\circ} \mathrm{C}$ of clear film; instead, during the spring months (end of March-end of May), the trend was inverted and the temperature under clear film was even $1^{\circ} \mathrm{C}$ more than that of diffuse-light film. In previous research on spinach, we also found that diffuse-light film in winter months (January-March) slightly increased the mean temperature with respect to clear film $\left(7.59{ }^{\circ} \mathrm{C}\right.$ vs. $\left.7.37^{\circ} \mathrm{C}\right)[40]$.

The different environmental conditions significantly affected the yield. The diffuselight film enhanced rocket production with a 36.0\% increase over the clear film. This increase was probably due to the higher light intensity that directly and positively affected the photosynthesis that is the main factors influencing plant productivity [32]. On the other hand, the positive effect of diffuse light on crop yield is well known [43]. In addition, in the current research, we also noted that the diffuse-light film was also able to greatly boost the yield along the six harvests. Under this film, the yield showed increased values until the fifth harvest, conversely to clear film where the yield increased only until the third harvest. It could be possible that in the spring months under the clear film, the plants were subjected to higher direct sunlight with a possible consequent detrimental effect on crop productivity; indeed, under direct light conditions, high light levels can often occur, which can lead to photosynthetic saturation with a consequent lower light use efficiency [24]. In addition, slightly higher maximum temperatures were registered, which overcame $35{ }^{\circ} \mathrm{C}$ in the first ten days of April with respect to $32.9{ }^{\circ} \mathrm{C}$ under Film1 (data not reported). In fact, the combination of high sunlight intensity, high crop temperature and vapor pressure deficit (VPD) can negatively affect photosynthesis and, consequently, the production [44]. Moreover, the optimal temperature range for rocket is reported as $15-22^{\circ} \mathrm{C}$. In their study on aeroponically grown rocket, $\mathrm{He}$ et al. [45] tested four different root-zone temperatures $\left(20^{\circ} \mathrm{C}-\mathrm{RZT}, 25^{\circ} \mathrm{C}-\mathrm{RZT}, 30^{\circ} \mathrm{C}-\mathrm{RZT}\right.$ and fluctuating ambient temperatures ranged from $25^{\circ} \mathrm{C}$ to $38^{\circ} \mathrm{C}$ ). They found that under ambient temperatures, the plants showed the lowest shoot and root fresh weight, while plants grown under $20^{\circ} \mathrm{C}$-RZT had the highest productivity of shoot and root. On the other hand, some authors claimed that plants grown under diffuse light conditions suffer fewer stress events related to water and heat [33,34]. Finally, under diffuse-light film, the plants fertilized with half of the optimal $\mathrm{N}$ dose reached the same yield value of the full-fertilized plant and grown under the clear film. Interestingly, the booster effect of this film was greater in N1 plants $(47.6 \%$ more than the corresponding plants of clear film); it elicited an intermediate effect on unfertilized plants and lower on plants fertilized with optimal dose. In effect, it seems that in optimal conditions (full fertilization), when the plants already showed the best productive performance, the room for improvement is lower, equal to what happened in very limiting conditions (no $\mathrm{N}$ fertilization). Similarly, the yield increased due to the diffuse-light film in plants not treated with biostimulant but was lower than that recorded in treated plants $(+29.1 \%$ and $+40.9 \%$, respectively). The beneficial effect of the diffuse light on crop performance was previously reported [46,47]. Kanniah et al. [30] commented on the "diffuse fertilization effect" referring to the plant production increase because of a more efficient yield per unit 
of PAR. Additionally, in our previous research on spinach grown under the same films, we found that the diffuse-light film elicited a $22 \%$ increase in yield [40]. The yield increase can be explained with a better uniform distribution of light that illuminates the canopy, with radiations coming from all directions [31]. In addition, considering that the diffuse-light film has a partial transmittivity in the UV-B range, this property could have equally affected the yield. Indeed, a previous study on spinach grown in different light conditions (standard growing conditions, no additional lighting; additional PAR; and three different intensity of UV-B) found that fresh and dry weight increased under additional PAR and intensive UV-B [21]. Some researchers reported that the plant growth response to UV-A and UV-B radiation depends on the plant species [48,49]; as a matter of fact, UV-B reduces the growth of lettuce [50], increases the growth of basil [51], and has no effect on maize [52].

The increase in yield was certainly due to the higher number of leaves per plant and leaf average weight recorded for plants grown under diffuse-light film.

The highest value of SPAD index was recorded in plants grown under diffuse-light film. The increase in SPAD elicited by this film was $2.1 \%$, less than that we recorded for spinach (4.6\% [40]) and lambs' lettuce (3\% [44]). The SPAD index was also directly linked to nitrogen dose both in treated and untreated plants with biostimulant, but in the last ones, the nitrogen fertilization effect was more marked: $+25.2 \%$ over unfertilized plants vs. $+15.9 \%$ recorded for treated plants. The effects of all experimental factors on the CIELAB color parameters were less evident, as similarly found for spinach [40], although slightly higher values of $a^{*}$ and $b^{*}$ color parameters were found under diffuse-light film, as reported in lamb's lettuce [44].

The main quality parameter of green leafy vegetables including rocket is undoubtedly the nitrate content in leaves. It depends on many factors, such as the genetic pool and environmental (e.g., solar radiation) and technical (e.g., nitrogen availability) factors but also on nitrate reductase activity. The nitrate content usually shows a seasonal trend, higher in winter than spring. In previous studies on lettuce, we found that plants cultivated in the winter period had a higher content of nitrate in leaves (about $2400 \mathrm{mg} \mathrm{kg}^{-1} \mathrm{fw}$ [16]) than the same plants grown in the spring period (1900 $\mathrm{mg} \mathrm{kg}^{-1}$ of fw [17]). In the current research, irrespective of the experimental conditions, we also found a decrease in nitrate content in spring harvests (IV-VI), while the higher value was recorded in the third harvest. The values of nitrate content of leaves rocket were always within the limits fixed by the European Community [53]. Our results are in line with the findings of Bonasia et al. [54], which reported a consistent decrease in nitrate content of wild rocket grown during winter-spring with respect to plants grown during the autumn-winter season (1472 vs. $3461 \mathrm{mg} \mathrm{kg}^{-1} \mathrm{fw}$, respectively). The specific trend highlighted for this parameter is probably strongly linked both to the nitrate reductase activity, which is stimulated by a high radiation condition [13], and also the $\mathrm{N}$ availability. Indeed, as previously stated, the nitrate content of leaves increased with $\mathrm{N}$ level increments: 1096, 3696, and 4963 ppm for $\mathrm{N} 0$, N1, and N2, respectively. These results are in line with many findings reported by several authors on green vegetables [40,44,55-57]. Interestingly, in all conditions, at the second harvest (February) a low value of nitrate in leaves was noted. In addition, in this month, we also recorded the lowest value of soil N-NO3 content (17.4 ppm with respect to $22.9,143.4,183.1,222.7$, and $63.8 \mathrm{ppm}$ for I, III, IV, V, and VI harvest, respectively, data not shown). Two reasons could explain this result: (i) the second cycle was the longest (68 days); therefore, the interval of time between the last $\mathrm{N}$ fertilization and the harvest was higher (38 days, see Table 1); therefore, there was more time for metabolizing the nitrogen; (ii) there was a lower content of nitrate in the soil (Table 2) due to the longer crop cycle, explaining the greater $\mathrm{N}$ uptake by plants.

In addition, we also observed an increase in nitrate content in rocket leaves of plants treated with biostimulant with respect to those that were untreated (3924 vs. $2580 \mathrm{ppm}$ ), although the manufacturer reports that "Stimolo Mo" can stimulate the nitrate reductase activity, thus reducing the nitrate content. The value of the treated plants was higher under the clear film, 5386 vs. 4585 ppm of plants under the diffuse-light film. The optical 
properties of this cover film seem to amplify the effect of biostimulant; indeed, the difference between the two films was less marked for untreated plants (4340 vs. 4080 ppm, respectively). Moreover, the effect of film-biostimulant combination also varied during the growing period. In the last cycle, under clear film, the biostimulant application elicited a $66 \%$ increase in nitrate content with respect to $24.1 \%$ recorded for the March harvest, while these increases were $14.1 \%$ and $30.6 \%$ under diffuse-light film for the third and sixth harvest, respectively.

\section{Conclusions}

The diffuse-light film seemed to be useful to obtain a higher yield with a halved $\mathrm{N}$ dose, as well as in combination with biostimulant application, which strongly boosted the yield. In addition, the diffuse-light film had no strong effect on the increase in nitrate content in leaves, in contrast with nitrogen fertilization and biostimulant application. Indeed, this last one did not confirm the capacity to contain nitrate, at least for this crop and in this cultivation system with such environmental conditions, although nitrate levels were maintained within the legal limit fixed by the European Commission. Further research is needed to verify whether this response can be linked to the species and/or cultivation system.

Author Contributions: Conceptualization, M.M., E.C., I.D.M. and Y.R.; methodology, M.M., E.C., I.D.M. and Y.R.; software, L.O., G.C. and C.E.-N.; validation, M.M., P.M. and Y.R.; formal analysis, M.R., I.D.M. and L.O.; investigation, I.D.M. and C.E.-N.; resources, E.C. and G.C.; data curation, M.M. and Y.R.; writing-original draft preparation, I.D.M. and L.O.; writing-review and editing, I.D.M., C.E.-N., G.C., L.O. and Y.R.; visualization, L.O., E.C. and C.E.-N.; supervision, M.M., M.R., P.M. and Y.R.; project administration, M.M. and P.M.; funding acquisition, M.M. All authors have read and agreed to the published version of the manuscript.

Funding: This research received no external funding.

Data Availability Statement: The datasets generated for this study are available on request to the corresponding author.

Acknowledgments: We would like to thank Sabrina Nocerino and Ida Romano for their support in laboratory work.

Conflicts of Interest: The authors declare no conflict of interest.

\section{References}

1. D'Antuono, L.F.; Elementi, S.; Neri, R. Glucosinolates in Diplotaxis and Eruca leaves: Diversity, taxonomic relations and applied aspects. Phytochemistry 2008, 69, 187-199. [CrossRef] [PubMed]

2. Martínez-Sánchez, A.; Llorach, R.; Gil, M.I.; Ferreres, F. Identification of new flavonoid glycosides and flavonoid profiles to characterize rocket leafy salads (Eruca vesicaria and Diplotaxis tenuifolia). J. Agric. Food Chem. 2007, 55, 1356-1363. [CrossRef] [PubMed]

3. Siomos, A.S.; Koukounaras, A. Quality and postharvest physiology of rocket leaves. Fresh Prod. 2007, 1, 59-65.

4. Non Renseigné, U.A.; Iqbal, M. Nitrate accumulation in plants, factors affecting the process, and human health implications. A review. Agron. Sustain. Dev. 2007, 27, 45-57.

5. Colla, G.; Kim, H.J.; Myriacou, M.C.; Rouphael, Y. Nitrate in fruits and vegetables. Sci. Hortic. 2018, 237, 221-238. [CrossRef]

6. Salehzadeh, H.; Maleki, A.; Rezaee, R.; Shahmoradi, B.; Ponnet, K. The nitrate content of fresh and cooked vegetables and their health-related risks. PLoS ONE 2020, 15, e0227551. [CrossRef]

7. Cavaiuolo, M.; Ferrante, A. Nitrates and glucosinolates as strong determinants of the nutritional quality in rocket leafy salads. Nutrients 2014, 6, 1519-1538. [CrossRef]

8. Barker, A.V.; Maynard, D.N. Nutritional factors affecting nitrate accumulation in spinach. Commun. Soil Sci. Plant Anal. 1971, 2, 47. [CrossRef]

9. Stagnari, F.; Di Bitetto, V.; Pisante, M. Effects of N fertilizers and rates on yield, safety and nutrients in processing spinach genotypes. Sci. Hortic. 2007, 114, 225-233. [CrossRef]

10. Abubaker, S.M.; Abu-Zahra, T.R.; Alzubi, Y.A.; Tahboub, A.B. Nitrate accumulation in spinach (Spinacia oleracea L.) tissues under different fertilization regimes. J. Food Agric. Environ. 2010, 8, 778-780.

11. Breimer, T. Environmental factors and cultural measures affecting the nitrate content in spinach. Fert. Res. 1982, 3, 191-292. [CrossRef] 
12. Di Mola, I.; Cozzolino, E.; Ottaiano, L.; Nocerino, S.; Rouphael, Y.; Colla, G.; El-Nakhel, C.; Mori, M. Nitrogen Use and Uptake Efficiency and Crop Performance of Baby Spinach (Spinacia oleracea L.) and Lamb's Lettuce (Valerianella locusta L.) Grown under Variable Sub-Optimal N Regimes Combined with Plant-Based Biostimulant Application. Agronomy 2020, 10, 278. [CrossRef]

13. Bian, Z.; Wang, Y.; Zhang, X.; Li, T.; Grundy, S.; Yang, Q.; Cheng, R. A Review of Environment Effects on Nitrate Accumulation in Leafy Vegetables Grown in Controlled Environments. Foods 2020, 9, 732. [CrossRef] [PubMed]

14. Fu, Y.; Li, H.Y.; Yu, J.; Liu, H.; Cao, Z.Y.; Manukovsky, N.S.; Liu, H. Interaction effects of light intensity and nitrogen concentration on growth, photosynthetic characteristics and quality of lettuce (Lactuca sativa L. Var. youmaicai). Sci. Hort. 2017, 214, 51-57. [CrossRef]

15. Santamaria, P. Nitrate in vegetables: Toxicity, content, intake and EC regulation. J. Sci. Food Agric. 2006, 86, 10-17. [CrossRef]

16. Di Mola, I.; Rouphael, Y.; Colla, G.; Fagnano, M.; Paradiso, R.; Mori, M. Morph physiological traits and nitrate content of greenhouse lettuce as affected by irrigation with saline water. HortScience 2017, 52, 1716-1721. [CrossRef]

17. Di Mola, I.; Rouphael, Y.; Ottaiano, L.; Duri, L.G.; Mori, M.; De Pascale, S. Assessing the effects of salinity on yield, leaf gas exchange and nutritional quality of spring greenhouse lettuce. Acta Hortic. 2018, 1227, 479-484. [CrossRef]

18. Caruso, G.; Formisano, L.; Cozzolino, E.; Pannico, A.; El-Nakhel, C.; Rouphael, Y.; Tallarita, A.; Cenvinzo, V.; De Pascale, S. Shading affects Yield, Elemental Composition and Antioxidants of Perennial Wall Rocket Crops Grown from Spring to Summer in Southern Italy. Plants 2020, 9, 933. [CrossRef]

19. Drews, M.; Schonhof, I.; Krumbein, A. Influence of growth season on the content of nitrate, vitamin C, beta-carotin, and sugar of head lettuce under greenhouse conditions. Gartenbauwissenschaft 1995, 60, 180-187.

20. Department of Energy. Available online: https://www.energy.gov/eere/solar/solar-radiation-basics (accessed on 19 November 2021).

21. Heuberger, H.; Preager, U.; Georgi, M.; Schirrmacher, G.; Graßmann, J.; Schnitzler, W.H. Precision stressing by UV-B radiation to improvequality of spinach under protected cultivation. Acta Hort. 2004, 659, 201-206. [CrossRef]

22. Peet, M.M. Greenhouse crop stress management. Acta Hort. 1999, 481, 643-654. [CrossRef]

23. Warren, W.J.; Hand, D.W.; Hannah, M.A. Light interception and photosynthetic efficiency in some glasshouse crops. J. Exp. Bot. 1992, 43, 363-373.

24. Li, T.; Yang, Q. Advantages of diffuse light for horticultural production and perspectives for further research. Front. Plant Sci. 2015, 6, 704. [CrossRef]

25. Gu, L.; Baldocchi, D.D.; Wofsy, S.C.; William Munger, J.; Michalsky, J.J.; Urbanski, S.P.; Boden, T.A. Response of a deciduous forest to the Mount Pinatubo eruption: Enhanced photosynthesis. Science 2003, 299, 2035-2038. [CrossRef] [PubMed]

26. Marcelis, L.F.M.; Broekhuijsen, A.G.M.; Meinen, E.; Nijs, E.M.F.M.; Raaphorst, M.G.M. Quantification of the growth response to light quantity of greenhouse grown crops. Acta Hortic. 2006, 711, 97-103. [CrossRef]

27. Poorter, H.; Anten, N.P.R.; Marcelis, L.F.M. Physiological mechanisms in plant growth models: Do we need a supra-cellular systems biology approach? Plant Cell Environ. 2013, 36, 1673-1690. [CrossRef]

28. Fausey, B.A.; Heins, R.D.; Cameron, A.C. Daily light integral affects flowering and quality of greenhouse-grown Achillea, Gaura, and Lavandula. HortScience 2005, 40, 114-118. [CrossRef]

29. Hemming, S.; Dueck, T.; Janse, J.; Van Noort, F. The effect of diffuse light on crops. Acta Hortic. 2008, 801, 1293-1300. [CrossRef]

30. Kanniah, K.D.; Beringer, J.; North, P.; Hutley, L. Control of atmospheric particles on diffuse radiation and terrestrial plant productivity: A review. Prog. Phys. Geogr. 2012, 36, 209-237. [CrossRef]

31. Roderick, M.L.; Farquhar, G.D.; Berry, S.L.; Noble, I.R. On the direct effect of clouds and atmospheric particles on the productivity and structure of vegetation. Oecologia 2001, 129, 21-30. [CrossRef]

32. Di Mola, I.; Conti, S.; Cozzolino, E.; Melchionna, G.; Ottaiano, L.; Testa, A.; Sabatino, L.; Rouphael, Y.; Mori, M. Plant-Based protein hydrolysate improves salinity tolerance in hemp: Agronomical and physiological aspects. Agronomy 2021, 11, 342. [CrossRef]

33. Urban, O.; Klem, K.; Ač, A.; Havránková, K.; Holišová, P.; Navrátil, M.; Zitová, M.; Kozlová, K.; Pokorný, R.; Šprtová, M.; et al. Impact of clear and cloudy sky conditions on the vertical distribution of photosynthetic $\mathrm{CO}_{2}$ uptake within a spruce canopy. Funct. Ecol. 2012, 26, 46-55. [CrossRef]

34. Steiner, A.L.; Chameides, W.L. Aerosol-induced thermal effects increase modelled terrestrial photosynthesis and transpiration. Tellus B Chem. Phys. Meteorol. 2005, 57, 404-411. [CrossRef]

35. Colla, G.; Nardi, S.; Cardarelli, M.; Ertani, A.; Lucini, L.; Canaguier, R.; Rouphael, Y. Protein hydrolysates as biostimulants in horticulture. Sci. Hortic. 2015, 196, 28-38. [CrossRef]

36. Colla, G.; Hoagland, L.; Ruzzi, M.; Cardarelli, M.; Bonini, P.; Canaguier, R.; Rouphael, Y. Biostimulant action of protein hydrolysates: Unraveling their effects on plant physiology and microbiome. Front. Plant Sci. 2017, 8, 2202. [CrossRef]

37. Rouphael, Y.; Colla, G. Synergistic biostimulatory action: Designing the next generation of plant biostimulants for sustainable agriculture. Front. Plant Sci. 2018, 9, 1655. [CrossRef]

38. Chiaiese, P.; Corrado, G.; Colla, G.; Kyriacou, M.C.; Rouphael, Y. Renewable sources of plant biostimulation: Microalgae as a sustainable means to improve crop performance. Front. Plant Sci. 2018, 9, 1782. [CrossRef]

39. Maraldisementi. Available online: https://www.maraldisementi.it/en/wild-rocket/ (accessed on 19 November 2021). 
40. Di Mola, I.; Ottaiano, L.; Cozzolino, E.; Sabatino, L.; Sifola, M.I.; Mormile, P.; Mori, M. Optical Characteristics of greenhouse plastic films affect yield and some quality traits of spinach (Spinacia oleracea L.) Subjected to Different Nitrogen Doses. Horticulturae 2021, 7, 200. [CrossRef]

41. Fertenia. Available online: https://www.fertenia.it/schede/biostimolanti/stimolo.pdf (accessed on 19 November 2021).

42. Bremner, J.M. Total nitrogen. In Methods of Soil Analysis. Agronomy Monograph; Part 2; Black, C.A., Evans, D.D., White, I.L., Ensminger, L.E., Clark, F.E., Eds.; American Society of Agronomy: Madison, WI, USA, 1965; Volume 9, pp. 1149-1178.

43. Jiang, H.; Yang, Y.; Wang, H.; Bai, Y.; Bai, Y. Surface Diffuse Solar Radiation Determined by Reanalysis and Satellite over East Asia: Evaluation and Comparison. Remote Sens. 2020, 12, 1387. [CrossRef]

44. Cozzolino, E.; Di Mola, I.; Ottaiano, L.; El-Nakhel, C.; Mormile, P.; Rouphael, Y.; Mori, M. The potential of greenhouse diffusing cover material on yield and nutritive values of lamb's lettuce grown under diverse nitrogen regimes. Italus Hortus 2020, 27, 55-67. [CrossRef]

45. He, J.; See, X.E.; Qin, L.; Choong, T.W. Effects of root-zone temperature on photosynthesis, productivity and nutritional quality of aeroponically grown salad rocket (Eruca sativa) vegetable. Am. J. Plant Sci. 2016, 7, 1993-2005. [CrossRef]

46. Duek, T.; Janse, J.; Li, T.; Kempkes, F.; Eveleens, B. Influence of diffuse glass on the growth and production of tomato. Acta Hort. 2012, 956, 75-82. [CrossRef]

47. Chun, H.; Yum, S.; Kang, Y.; Kim, H.; Lee, S. Environments and canopy productivity of green pepper (Capsicum annuum L.) in a greenhouse using light-diffused woven film. Korean J. Hortic. Sci. Technol. 2005, 23, 367-371.

48. Neugart, S.; Schreiner, M. UVB and UVA as eustressors in horticultural and agricultural crops. Sci. Hort. 2018, $234,370-381$. [CrossRef]

49. Kittas, C.; Tchamitchian, M.; Katsoulas, N.; Karaiskou, P.; Papaioannou, C.H. Effect of two UV-absorbing greenhouse-covering films on growth and yield of an eggplant soilless crop. Sci. Hort. 2006, 110, 30-37. [CrossRef]

50. Paul, N.D.; Moore, J.P.; McPherson, M.; Lambourne, C.; Croft, P.; Heaton, J.C.; Wargent, J.J. Ecological responses to UV radiation: Interactions between the biological effects of UV on plants and on associated organisms. Phys. Plant. 2012, 145, 565-581. [CrossRef]

51. Sakalauskaite, J.; Viškelis, P.; Duchovskis, P.; Dambrauskiene, E.; Sakalauskiene, S.; Samuoliene, G.; Brazaityte, A. Supplementary UV-B irradiation effects on basil (Ocimum basilicum L.) growth and phytochemical properties. J. Food Agric. Environ. 2012, 10, 342-346.

52. Pal, M.A.; Sharma, A.; Abrol, Y.P.; Sengupta, U.K. Exclusion of UV-B radiation from normal solar spectrum on growth of mung bean and maize. Agric. Ecosyst. Environ. 1997, 61, 29-34. [CrossRef]

53. European Community. Reg. n 1258 of 2 December 2011. Off. J. Eur. Union 2011, L320, 15-17.

54. Bonasia, A.; Lazzizera, C.; Elia, A.; Conversa, G. Nutritional, biophysical and physiological characteristics of wild rocket genotypes as affected by soilless cultivation system, salinity level of nutrient solution and growing period. Front. Plant Sci. 2017, 8, 300. [CrossRef]

55. Di Mola, I.; Ottaiano, L.; Cozzolino, E.; Senatore, M.; Giordano, M.; El-Nakhel, C.; Mori, M. Plant-based biostimulants influence the agronomical, physiological, and qualitative responses of baby rocket leaves under diverse nitrogen conditions. Plants 2019, 8, 522. [CrossRef] [PubMed]

56. Di Mola, I.; Cozzolino, E.; Ottaiano, L.; Giordano, M.; Rouphael, Y.; Colla, G.; Mori, M. Effect of vegetal-and seaweed extractbased biostimulants on agronomical and leaf quality traits of plastic tunnel-grown baby lettuce under four regimes of nitrogen fertilization. Agronomy 2019, 9, 571. [CrossRef]

57. Di Mola, I.; Cozzolino, E.; Ottaiano, L.; Giordano, M.; Rouphael, Y.; El Nakhel, C.; Mori, M. Effect of seaweed (Ecklonia maxima) extract and legume-derived protein hydrolysate biostimulants on baby leaf lettuce grown on optimal doses of nitrogen under greenhouse conditions. Aust. J. Crop. Sci 2020, 14, 1456-1464. [CrossRef] 